\title{
Investigation of the Effects of Methylphenidate, an Amphetamine Derivative, on Intervertebral Disc Tissue Cell Cultures and Matrix Structures
}

\author{
Yasin Emre KAYA ${ }^{1}$, Numan KARAARSLAN², Duygu YASAR SIRIN³, Hanefi OZBEK ${ }^{4}$, Necati KAPLAN ${ }^{5}$ \\ Ibrahim YILMAZ4

\begin{abstract}
${ }^{1}$ Bolu Abant Izzet Baysal University, School of Medicine, Department of Orthopaedics and Traumatology, Bolu, Turkey ${ }^{2}$ Namik Kemal University, School of Medicine, Department of Neurosurgery, Tekirdag, Turkey ${ }^{3}$ Namik Kemal University, Faculty of Arts and Sciences, Department of Molecular Biology and Genetics, Tekirdag, Turkey ${ }^{4}$ Istanbul Medipol University, School of Medicine, Department of Medical Pharmacology, Istanbul, Turkey

Istanbul Rumeli University, Corlu Reyap Hospital, Department of Neurosurgery, Tekirdag, Turkey
\end{abstract}

Corresponding author: Numan KARAARSLAN numikara@yahoo.com

\section{ABSTRACT}

AIM: To investigate the effects of methylphenidate (MPH), on intervertebral disc tissue (IVD) cell cultures and extracellular matrix structures. Changes in the expression of some important marker genes involved in anabolic and catabolic mechanisms of IVD extracellular matrix formation were also evaluated.

MATERIAL and METHODS: Primary cultures of nucleus pulposus cells (NPCs) and annulus fibrosus cells (AFCs) were isolated from tissues obtained from the operated patients. Cell viability and proliferation were tested, and the cell surface morphologies were evaluated by microscopy. The expressions of the chondroadherin (CHAD), cartilage oligomeric matrix protein (COMP), interleukin-1 beta (IL-1 3 ) and matrix metalloproteinase (MMP) -7 and MMP-19 genes were evaluated using the quantitative real-time polymerase chain reaction (qRT-PCR). A value of $p<0.05$ was considered statistically significant.

RESULTS: The viability and proliferation of intervertebral disc tissue cells decreased in response to MPH treatment and the expression of the investigated genes also changed.

CONCLUSION: The data obtained from in-vitro studies may not directly adaptable to clinical applications. However, the fact that the central nervous system stimulant MPH can suppress proliferation of cells derived from IVD tissue should be considered carefully by clinicians.

KEYWORDS: Cartilage oligomeric matrix protein, Chondroadherin, Interleukin-1 beta, Intervertebral disc, Matrix metalloproteinase, Methylphenidate

\section{INTRODUCTION}

$\mathrm{M}$ ethylphenidate $(\mathrm{MPH})$ is a pharmacological agent used for the treatment of attention-deficithyperactivity disorder (ADHD) due to its psychostimulant effect in children and adolescents aged between 6 and 18 years (6). $\mathrm{MPH}$ is often prescribed for patients with ADHD to improve attention and concentration and to reduce impulsive behaviors by increasing activities in certain areas of the brain that function below the normal level (7).

Some important cardiovascular and neurological side effects after the use of MPH have previously been reported $(14,25,26)$. The relevant literature also indicates other side
Yasin Emre KAYA

(D) : 0000-0002-5412-8355

Numan KARAARSLAN (D) : 0000-0001-5590-0637

Duygu YASAR SIRIN (D) : 0000-0002-1224-442X
Hanefi OZBEK (D): 0000-0002-8084-7855

Necati KAPLAN (D) : 0000-0001-5672-0566

Ibrahim YILMAZ (D) : 0000-0003-2003-6337 
effects, including swelling of the face, lips, tongue, or other parts of the body; shortness of breath or difficulty in breathing; rhabdomyolysis; and visual impairment $(5,19)$. A variety of studies have also suggested that administration of MPH, an amphetamine derivative, may lead to a decrease in red blood cells, white blood cells, and platelets (6).

Some studies have reported that growth in almost every period of childhood may be adversely affected due to the induction of bone development disorders involving chondrodystrophies or the use of certain drugs $(5,6)$. Indeed, a suppression of height increases in children has been reported after high-dose and long-term MHP administration (5,6). In addition to these known adverse events, invivo research has examined the adverse effects of MPH on human primary chondrocyte cultures (6). However, no studies have yet focused on the possible damage MHP administration may inflict on intervertebral disc (IVD) tissue. The aim of the present study was to investigate the potential effects of MPH, as a commonly prescribed drug for the treatment of patients with ADHD, on cultures of primary human nucleus pulposuscells (NPCs) and annulus fibrosus cells (AFCs). Cell viability, proliferation, and toxicity analyses were performed and the morphologies of cellular and matrixlike structures were also analyzed by microscopy.

The expression of chondroadherin (CHAD) (10), an NPCspecific marker, was also examined. The level of the cartilage oligomeric matrix protein (COMP) $(3,8)$, an extracellular matrix protein thatis involved in intervertebral disc catabolic metabolism, was also determined. In addition to these markers, the levels of matrix metalloproteinase (MMP)-7 and MMP-19 $(16,23,24)$ and interleukin (IL)-1 $\beta(10)$, the main proinflammatory cytokine of the intervertebral disc, were examined using the quantitative reverse transcriptase realtime polymerase chain reaction (qRT-PCR).

\section{MATERIAL and METHODS}

The present research was approved by the Local Ethics Committee of Istanbul Medipol University (no. 29.11.201710840098/604.01.01/E.44192), Faculty of Medicine. Analyses were performed by the same researchers and repeated at least three times to minimize the experimental errors. Cell cultures were prepared from the tissues extracted from patients with spinal trauma who underwent operations after neurological examinations. Written consent forms were obtained from all the patients undergoing surgery whose tissues were used in the preparation of the primary cell cultures. Researchers were blinded to the dosages and drugs, i.e., the components in the culture medium. Primary cell cultures were fed every two days with freshly prepared culture medium. Cells reaching 95\% confluency were assayed in third passages.

\section{Materials}

The 3 - (4, 5 - dimethylthiazol - 2 - yl) - 2,5- diphenyltetrazolium bromide (MTT) assay was performed using a commercial kit (Vybrant MTT Cell Proliferation Assay, Cat. no. V-13154; Cell Biolabs, USA). Gene expression assays were performed using a PureLink RNA Mini kit (cat. No. 12183018A; Ambion; Thermo Fisher Scientific, Inc.) and 2-mercaptoethanol
(Thermo Fisher Scientific, Inc.). Purified RNA (50 ng) was reverse transcribed to obtain complementary DNA (cDNA) using a High Capacity cDNA Reverse Transcription kit (cat. no. 4368814; Thermo Fisher Scientific, Inc.), according to the manufacturer's protocol. The CDNA was used for the qPCR analyses to analyze the changes in gene expression using TaqMan Gene Expression Assays kits for CHAD (cat. no. 4331182, Hs00154382_m1); COMP (cat. no. 4331182, Hs00164359_m1), IL-1ß (cat. no. 4331182, Hs01555410_m1), MMP -7 (cat. no. 4331182, Hs01042796_m1),and MMP19 (cat. no. 4331182, Hs00418247_g1). $\beta$-actin (cat. no. 4331182, Hs01060665_g1; Thermo Fisher Scientific, Inc.) was used as the internal control (house keeping) gene. The Applied Biosystems 7300/7500 RT-PCR system was used for qRT-PCR.

\section{Criteria for the Inclusion or Exclusion of the Tissues Obtained from the Patients}

Of the 13 patients, the tissues of the following patients were excluded from the study: a patient with thyroid dysfunction $(n=1)$, a patient with glaucoma $(n=1)$, a patient with cerebral aneurysm $(n=1)$, and a patient with paralysis $(n=1)$. Two patients with a history of alcohol dependence $(n=2)$ and a patient $(n=1)$ using a monoamine oxidase inhibitor were also excluded. The remaining six patients (similar in terms of sex [3 male and 3 female], age, and body mass index) underwent operations and the resected IVD tissues from these patients were used for the preparation of primary cell cultures. Degenerated disc hernias compressing the nerve roots and/or the spinal cord were harvested, and the amount of disc degeneration was graded according to the Pfirrmann classification, using T2 weighted magnetic resonance imaging (MRI) scans (13). The ages of patients whose tissues (extruded or migrated disc fragments) were used varied from 22 years to 46 years, with a mean patient age of $36 \pm 3.78$ years

Further examinations were performed for patients with lumbar disc herniation who were unresponsive to conservative medical treatment. The decision for surgical intervention was made following preoperative neurological examination and lumbar spinal MRI scans and, if necessary, following lumbar spinal computerized tomography (CT) and lower extremity electromyography (EMG). The patients were operated on in the prone position under general anesthesia. The surgical level was confirmed using C-arm scopy. Surgical site antisepsis was provided, and the site was kept covered in a sterile manner. A midline incision was made approximately $2 \mathrm{~cm}$ above the surgical level. After the skin was penetrated with an incision, the paravertebral muscles were dissected subperiosteally. A partial hemilaminectomy and flavectomy were subsequently performed. The dura and spinal root were identified and medialized following the flavectomy. The microdiscectomy was completed using a disc punch after the disc capsule was incised with a surgical steel scalpel (no. 15 blade) $(9,13)$.

Following resection of the IVD tissue, the tissue samples were placed in sterile Falcon tubes containing Dulbecco's modified Eagle's medium (DMEM) supplemented with 5\% penicillin-streptomycin, $15 \%$ fetal bovine serum (FBS), and $1 \% \mathrm{~L}$-glutamine. The samples were then transferred to 
the laboratory at $4^{\circ} \mathrm{C}$. Falcon tubes were numbered so that researchers did not know which tissue sample had been obtained from which patient.

\section{Preparation of Cell Cultures from Human Primary IVD}

Tissue samples were irrigated consecutively three times with $0.9 \%$ isotonic sodium chloride solution in the laminar flow cabinet. The resulting mechanically degraded tissues were then transferred to Falcon tubes. A $0.375 \mathrm{mg}$ sample of collagenase type II enzyme, dissolved in a complete medium, was added, and the samples were incubated overnightin $5 \% \mathrm{CO}_{2}$ at $37^{\circ} \mathrm{C}$. The samples were then centrifuged twice at $1200 \mathrm{rpm}$ [112 Relative Centrifugal Force (RCF)] for 5 minutes, following the protocol described by Karaarslan et al. $(9-13,21)$. The obtained cell pellets were resuspended in cell culture medium and transferred to flasks. Confluent primary cell cultures were passaged. At the third passage, the cells were stained with trypan blue and counted under an inverted light microscope at 10x magnification. The counted cells were plated at various well plates to perform analyses. All the samples were then incubated in an incubator at $37.4^{\circ} \mathrm{C}$ with $5 \% \mathrm{CO}_{2}$.

\section{MPH Treatment of Cell Cultures}

The primary stock solution of MPH was made by dissolving $10 \mathrm{mg}$ in $4300 \mu \mathrm{M}$ dimethyl sulfoxide as described previously (1) and then diluted to $10,100,250$, and $1000 \mu \mathrm{M}$ final concentration and added to the primary cell cultures isolated from IVD tissue. All the analyses were performed at 0, 24, 48, and 72 hours (h).

\section{Inverted Light/Fluorescence Microscopy and Acridine Orange \& Propidiumiodide Staining}

Cell surface morphologies were examined under $4 x, 10 x, 20 x$, and 40x magnifications using an inverted light microscope (Olympus CKX41) and a fluorescence microscope (Leica; DM 2500). Analyses were performed at 24,48 , and $72 \mathrm{~h}$.

Cell viability was determined and the results of the MTT assay were confirmed using the nucleic acid binding dyes acridine orange $(\mathrm{AO})$ and propidium iodide $(\mathrm{PI})$. To prepare the AO/PI stain, $4 \mathrm{mg} \mathrm{AO}$ (dissolved in $2 \mathrm{ml} 99 \% \mathrm{ETOH}$ ), $10 \mathrm{~g}$ sodiumethylenediaminetetraacetic acid, $4 \mathrm{mg} \mathrm{PI}$, and $50 \mathrm{ml}$ FBS were mixed well and sterile distilled water was added to reach a $200 \mathrm{ml}$ final volume $(9,11-13,21)$. The $A O$ generates green fluorescence and stains all nucleated cells, whether alive or dead. By contrast, PI stains nucleated cells, but only dead cells with poor membrane integrity and generates red fluorescence. Microphotographs of cell organization were visualized using Cytovision Capture Station Imaging software.

\section{MTT Assay}

Cell viability analyses were performed using a commercial MTT kit. The MTT analyses were performed in all the control and experimental group samples before and after the drug administration. Analyses were performed at a wave length of $570 \mathrm{~nm}$ with an enzyme-linked immunosorbent assay (ELISA/ Optical density-OD) microplate reader (Mindray MR 96 A, $\mathrm{PRC})$.
The culture media containing MPH discarded from the $100 \mathrm{~mL}$ MTT wells $(12 \mathrm{mM} / 5 \mathrm{mg} \mathrm{MTT}$ prepared by adding $1 \mathrm{~mL}$ sterile phosphate buffer saline) was added. Cultures were incubated at $37 \mathrm{C}^{\circ}$ for $3 \mathrm{~h}$ in the dark. Dimethyl sulfoxide was added to these samples to stop the reaction and incubated at $37^{\circ} \mathrm{C}$ for an additional 10 minutes, followed by spectrophotometric absorbance measurements at $570 \mathrm{~nm}$. The control group consisted of cells without MPH administration and the control cell viability was taken as $100 \%$. The proliferation and the inhibition of the proliferation were calculated using the following formulas: "Test OD/ Control ODX100" and "1- Test $O D /$ Control $O D$," respectively, and the data were recorded for statistical analysis $(6,9-11,13,21)$.

\section{Gene Expression Analysis by qRT-PCR}

Total RNA was extracted from cultured primary human chondrocytes using the PureLink RNA mini kit. The quantity of RNA obtained from each sample was measured using a UV spectrophotometer. The cDNA was obtained by reverse transcription of $50 \mathrm{ng}$ RNA using a high capacity cDNA reverse transcription kit and a thermal cycler. All genes were amplified using TaqMan ${ }^{\circledR}$ Gene Expression assays for CHAD, ACT $\beta$, COMP, MMP-7, MMP-19, and IL-1 1 .The qPCR was performed on an Applied Biosystems 7300/7500 real-time PCR system (Thermo Fisher Scientific, Inc.), and the reaction mixture consisted of $1 \mu$ lTaqMan gene expression assay, 10 $\mu \mathrm{ITaqMan}$ gene expression master mix, $4 \mu \mathrm{l}$ cDNA template, and UltraPure DNase/RNase free distilled water for each gene, conducted in MicroAmp fast optical 96 well reaction plates. The thermocycling conditions were as follows: $2 \mathrm{~min}$ at $50^{\circ} \mathrm{C}, 10 \mathrm{~min}$ at $95^{\circ} \mathrm{C}, 15 \mathrm{sec}$ at $95^{\circ} \mathrm{C}$, and $1 \mathrm{~min}$ at $60^{\circ} \mathrm{C}$, for 40 cycles. The $R Q$ values of each sample from the RTqPCR experiment were obtained using the 7500 FastSDS program V.2.3 (Thermo Fisher Scientific, Inc.). An endogenous control (ACT $\beta$ ) was utilized to normalize the target gene expression (9-13,21).

\section{Statistical Analysis}

The statistical analyses were performed using Minitab (version 16.0, Minitab Ltd., Coventry, United Kingdom) software. Descriptive statistics were presented as the mean \pm standard deviation $(M \pm S D)$. An analysis of variance (ANOVA) test was performed to test for significant differences across the group means. When differences across groups were observed, Tukey's honestly significant difference (HSD) post-hoc test was used for multiple pairwise comparisons. The alpha significance value was accepted as $<0.05$.

\section{RESULTS}

The control group samples were viable and healthy and had a proliferation rate that reached approximately $95 \%$ confluency. In the control group cultures at $72 \mathrm{~h}$, the cells formed apophyses that spread to the extracellular matrix ora larger area (Figure 1A-C). However, the cell viability of the $\mathrm{MPH}$-treated samples showed time- and dose-dependent decreases. The characteristic morphology of the cells was disrupted, and the cells became rounder (Figure 1D-O). 


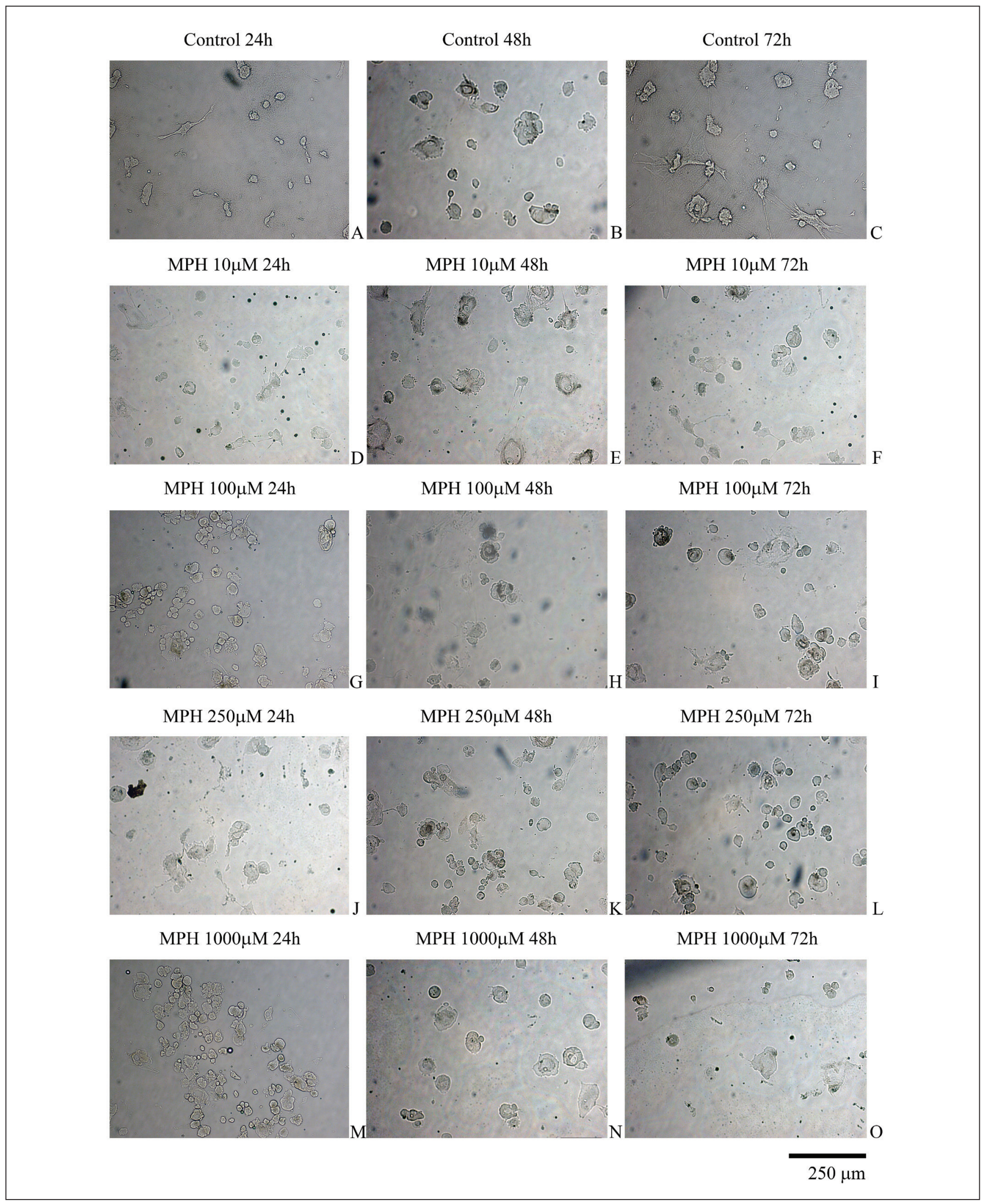

Figure 1: Evaluation of nucleus pulposus and annulus fibrosus cells by inverted light microscopy. The inverted light microscopy images were taken at magnifications of 10x, 20x, and 40x. 
The AO/PI staining revealed that MPH caused apoptotic cell death (Figure 2A-O). Although the application of highest dose $\mathrm{MPH}$ was expected to results in the greatest increase in cell death, the highest cell death was observed at $24 \mathrm{~h}$ following the administration of $100 \mu \mathrm{MMPH}$. The cell viability and proliferation gradually decreased in a time-dependent manner with increasing MPH concentration, and the differences were statistically significant $(F=14 ; p=0.000)$ (Table l).

All the gene expressions, except for MMP-19, increased with time in the control group samples. The expression of MMP-19 remained unchanged at $72 \mathrm{~h}$. Administration of 10 $\mu \mathrm{M} \mathrm{MPH}$ decreased the expression of CHAD approximately 2-fold $(R Q=0.32)$ at $24 \mathrm{~h}, 1.6$-fold at $48 \mathrm{~h}$, and 3.5 -fold at 72 $\mathrm{h}$ when compared to the control group. Administration of 100 $\mu \mathrm{M}$ MPH eliminated CHAD expression at $24 \mathrm{~h}$ and decreased the expression 1.6-fold at $48 \mathrm{~h}$ and 5.2 -fold at $72 \mathrm{~h}$ when compared to the control group samples. Administration of 250 $\mu \mathrm{M}$ MPH decreased CHAD expression approximately 1.6-fold $(R Q=0.41)$ at $24 \mathrm{~h}, 2.4$-fold at $48 \mathrm{~h}$, and 2.2 -fold at $72 \mathrm{~h}$ when compared to the control group samples. Administration of $1000 \mu \mathrm{M}$ MPH eliminated CHAD expression at $24 \mathrm{~h}$; however, CHAD expression was the same as in the control group at 48 $\mathrm{h}$, and it remained unchanged at $72 \mathrm{~h}$, so CHAD expression was less affected by administration of $1000 \mu \mathrm{M}$ MPH.
Administration of $10 \mu \mathrm{M}$ MPH decreased COMP expression approximately 4.4 -fold at $24 \mathrm{~h}, 1.4$-fold at $48 \mathrm{~h}$, and 1.7-fold at $72 \mathrm{~h}$, when compared to the control group. Administration of100 $\mu \mathrm{M}$ MPH decreased COMP expression 2.4-fold at 24 h, 1.7 -fold at $48 \mathrm{~h}$, and 1.5 -fold at $72 \mathrm{~h}$, when compared to the control group. Administration of $250 \mu \mathrm{M}$ MPH increased COMP expression 0.8-fold at $24 \mathrm{~h}$ and decreased COMP expression 2.6-fold at $72 \mathrm{~h}$, when compared to the control group. However, COMP was expressed at the same level as in the control group at $48 \mathrm{~h}$. Administration of $1000 \mu \mathrm{M} \mathrm{MPH}$ resulted in no change in COMP expression at $24 \mathrm{~h}$; however, COMP expression was increased 0.6 -fold at $48 \mathrm{~h}$ and 0.4 -fold at $72 \mathrm{~h}$, when compared to the control group.

Administration of $10 \mu \mathrm{M}$ MPH decreased IL-1 $\beta$ expression 2.1-fold at $24 \mathrm{~h}, 2.4$-fold at $48 \mathrm{~h}$, and 3.1-fold at $72 \mathrm{~h}$. Administration of $100 \mu \mathrm{M}$ MPH increased IL-1 $\beta$ expression 0.8 -fold at $24 \mathrm{~h}$, but decreased IL-1 $\beta$ expression 3.8 -fold at $48 \mathrm{~h}$, and 2.8-fold at $72 \mathrm{~h}$. Administration of $250 \mu \mathrm{M} \mathrm{MPH}$ decreased IL-1 $\beta$ expression 2.8-fold at $24 \mathrm{~h}$, but expression remained at the control level at $48 \mathrm{~h}$ and $72 \mathrm{~h}$. Administration of $1000 \mu \mathrm{M}$ MPH decreased IL-1 $\beta$ expression 3.2 -fold at $24 \mathrm{~h}$, 3.6-fold at $48 \mathrm{~h}$, and 4.3 -fold at $72 \mathrm{~h}$, when compared to the control group.

Table I: Evaluation of the Effects of MPH, Administered Different Concentrations, on the Cell Viability Through Tukey HSD Test After ANOVA

\begin{tabular}{|c|c|c|c|c|c|c|c|c|c|c|}
\hline Groups vs Times & Hours (h) & $\mathbf{n}$ & Mean $\pm S^{*} D^{*}$ & \multicolumn{7}{|c|}{ Grouping $^{*}$} \\
\hline Control & 72 & 8 & $0.374 \pm 0.01$ & A & & & & & & \\
\hline Control & 48 & 8 & $0.325 \pm 0.02$ & A & B & & & & & \\
\hline Control & 24 & 8 & $0.311 \pm 0.01$ & A & B & C & & & & \\
\hline Control & 0 & 8 & $0.289 \pm 0.01$ & & $\mathrm{C}$ & D & & & & \\
\hline $\mathrm{MPH} 1 \mu \mathrm{M}$ & 24 & 8 & $0.284 \pm 0.01$ & $\mathrm{~B}$ & $\mathrm{C}$ & D & E & & & \\
\hline $\mathrm{MPH} 1 \mu \mathrm{M}$ & 48 & 8 & $0.274 \pm 0.01$ & & $\mathrm{C}$ & $\mathrm{D}$ & $\mathrm{E}$ & & & \\
\hline MPH $100 \mu \mathrm{M}$ & 24 & 8 & $0.272 \pm 0.01$ & & $\mathrm{C}$ & D & $\mathrm{E}$ & $\mathrm{F}$ & & \\
\hline $\mathrm{MPH} 1 \mu \mathrm{M}$ & 72 & 8 & $0.269 \pm 0.01$ & & $\mathrm{C}$ & $\mathrm{D}$ & $\mathrm{E}$ & $\mathrm{F}$ & $\mathrm{G}$ & \\
\hline MPH $100 \mu \mathrm{M}$ & 48 & 8 & $0.264 \pm 0.02$ & & & D & E & $\mathrm{F}$ & $\mathrm{G}$ & \\
\hline MPH $500 \mu \mathrm{M}$ & 24 & 8 & $0.262 \pm 0.01$ & & & $\mathrm{D}$ & E & $\mathrm{F}$ & $\mathrm{G}$ & $\mathrm{H}$ \\
\hline MPH $500 \mu \mathrm{M}$ & 48 & 8 & $0.262 \pm 0.02$ & & & $\mathrm{D}$ & $\mathrm{E}$ & $\mathrm{F}$ & $\mathrm{G}$ & $\mathrm{H}$ \\
\hline $\mathrm{MPH} 1000 \mu \mathrm{M}$ & 24 & 8 & $0.253 \pm 0.02$ & & & $\mathrm{D}$ & $\mathrm{E}$ & $\mathrm{F}$ & $\mathrm{G}$ & $\mathrm{H}$ \\
\hline $\mathrm{MPH} 1000 \mu \mathrm{M}$ & 48 & 8 & $0.249 \pm 0.02$ & & & & $\mathrm{E}$ & $\mathrm{F}$ & G & $\mathrm{H}$ \\
\hline $\mathrm{MPH} 100 \mu \mathrm{M}$ & 72 & 8 & $0.242 \pm 0.01$ & & & & & $\mathrm{~F}$ & $\mathrm{G}$ & $\mathrm{H}$ \\
\hline MPH $500 \mu \mathrm{M}$ & 72 & 8 & $0.232 \pm 0.02$ & & & & & & $\mathrm{G}$ & $\mathrm{H}$ \\
\hline MPH $1000 \mu \mathrm{M}$ & 72 & 8 & $0.221 \pm 0.01$ & & & & & & & $\mathrm{H}$ \\
\hline
\end{tabular}

MPH: Methylphenidate, *: Analysis of variance, *: Tukey HSD test. A: Highest rate of viability and proliferation. Z: Lowest rate of viability and proliferation. 


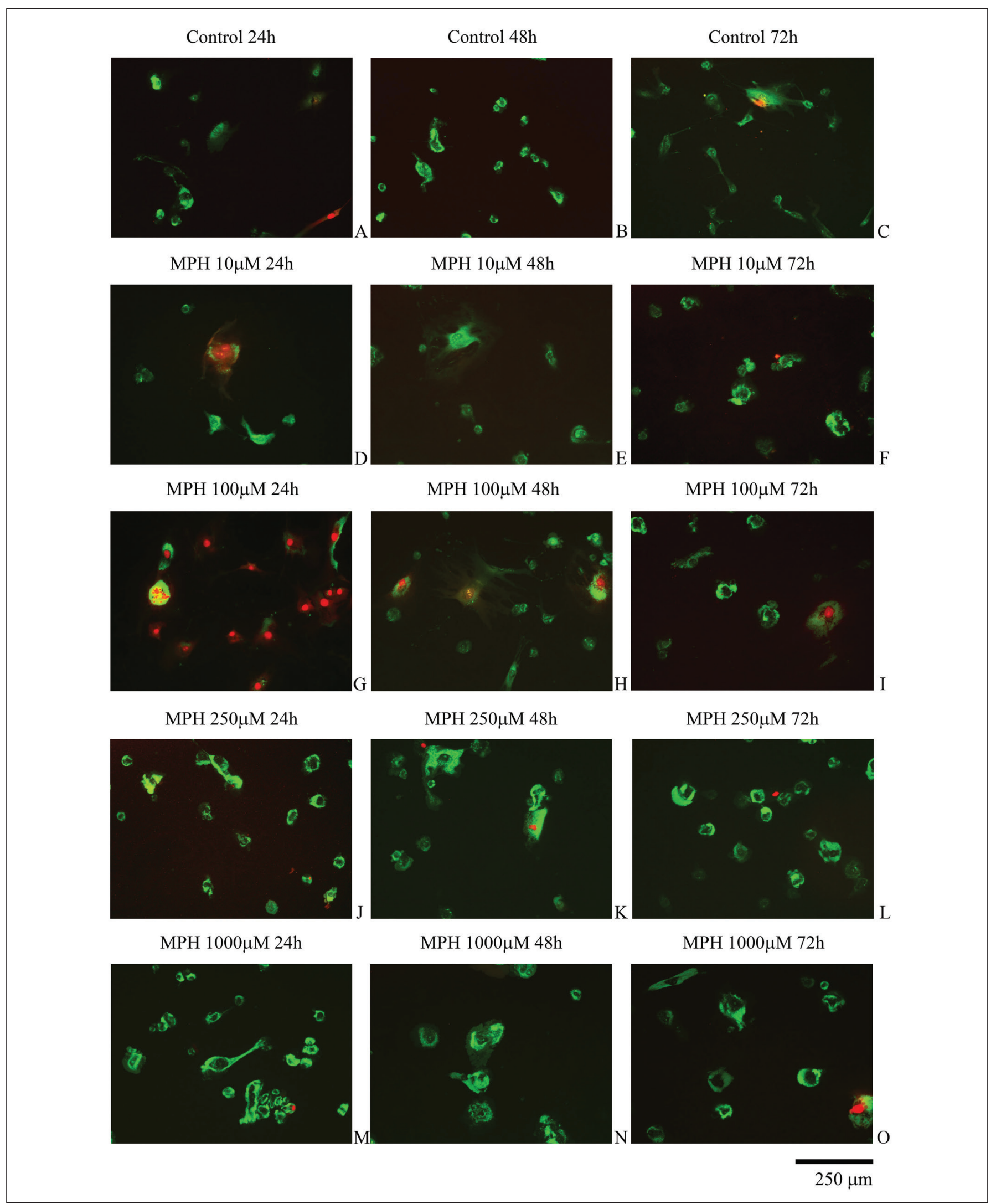

Figure 2: Evaluation of intervertebral disc tissue cells by fluorescence microscopy. The cells in groups with high concentrations of methylphenidate (MPH) and showing red nuclei and green cytoplasm are dead and have damaged membrane integrity. 
Administration of $10 \mu \mathrm{M}$ and $250 \mu \mathrm{M} \mathrm{MPH}$ resulted in no change in MMP-19 expression when compared to the control group. Administration of $1000 \mu \mathrm{M}$ MPH increased MMP-19 expression 0.7 -fold at $72 \mathrm{~h}$, when compared to the control group. At all other doses, administration of MPH decreased MMP-19 by 1.4 -fold to 1.9 -fold at 24,48 , and $72 \mathrm{~h}$, when compared to the control group.

Administration of $10 \mu \mathrm{M}$ MPH eliminated MMP-7 expression at $24 \mathrm{~h}$, and no MMP-7 expression was detected at $72 \mathrm{~h}$ following administration of $250 \mu \mathrm{M}$ MPH. MMP-7 expression was decreased 2.5 -fold at 24 by administration of $250 \mu \mathrm{M}$ $\mathrm{MPH}$, while it was increased 0.3 -fold and 0.7 -fold, respectively, following administration of 100 and $1000 \mu \mathrm{M} \mathrm{MPH}$. MMP-7 expression was increased 08.-fold at $48 \mathrm{~h}$ after administration of $1 \mu \mathrm{M} \mathrm{MPH}$, where asit was decreased 4.0-fold, 3.8-fold, and 1.3-fold, respectively, by administration of 100, 250, and 1000 $\mu \mathrm{M}$ MPH. MMP-7 expression was more strongly decreased at $72 \mathrm{~h}$, where it showed decreases of 7.6-fold, 7.3-fold, and 2.8fold, respectively, following administration of 1,100 , and 1000 $\mu M$ MPH $(p<0.05)$. The $R Q$ values obtained through $q R T-P C R$ analyses are presented in Figure 3.

\section{DISCUSSION}

Many drugs are known to accumulate in many tissues in the body, including the synovial fluid compartments $(9-13,21)$. Hence, drugs can diffuse from hyaluronan and synovial tissues into body fluids $(9-13,21)$ and they can pass through pores in the hyaline membranes located in the intervertebral disc space to reach the IVD cells $(9,21)$. In humans, the IVD tissue is fed through the arterial blood until the age of 18 . In the late twenties and early thirties, vascular feeding of the whole nucleus pulposus tissue and the peripheral part of the annulus fibrosus tissue is obliterated, and the disc tissue is then fed by diffusion from the environment that surrounds it $(9-11,13,21)$.

Gumustas et al. demonstrated the accumulation of MPH in synovial tissues (6), and reported a decrease in the viability, proliferation, and stage-specific embryonic antigen-1 protein expression in MHP-treated chondrocytes when compared to the control group. These researchers therefore cautioned clinicians not to overlook the fact that this drug may suppress chondrocyte cell proliferation and chondrogenic differentiation (6). However, in that study, the effects of MHP on cartilage tissues were solely investigated in vitro (6).

Overall, the results retrieved from the studies related to the treatment of ADHD using MPH are quite confusing. In invivo studies, MPH administration to young rats has been reported to results in smaller, less mineralized, and weaker bones in the appendicular region, and deteriorated bone quality (15). These findings agree with reports that adolescents treated with MPH have a high potential for long bone fractures. For example, the study by Batterson et al. (1), performed before 2005, concluded that MHP administration in children and adolescents might suppress growth and that delayed growth was associated with delayed tooth growth. However, Tehranchi et al. evaluated the dental age and cervical vertebral maturation in a study that also investigated ADHD for its potential role in delayed growth and development of children and reported that the deterioration of cervical vertebral maturation observed in children treated with MPH was also present in children not treated with MPH (22). No previous studies have focused on the positive or negative effects of MPH on disc tissue cells, such as IVD tissues or AFCs/NPCs. The aim of the present study was to investigate the potential effects of MPH, commonly prescribed for the treatment of patients with $A D H D$, on cells from human articular primary disc tissues.

Ludolph et al. reported that although MPH was the most commonly used drug in child and adolescent psychiatry, the knowledge of the pharmacological mechanism of MHP was incomplete (17). The authors investigated the toxic effects of MPH invitroin HEK-293 and HEK-hDAT cells and found that doses up to $1 \mathrm{mMdid}$ not affect the growth of HEK-hDAT cells or the survival of dopaminergic (DA) neurons for up to 72 hours. In that study, no differences in neuronal arborization or in the density of synapses were observed. Administration of 1-methyl-4-phenylpyridinium showed no toxic effect in HEK293 cells but had marked toxic effects in HEK-hDAT cells and DA neurons (17).

Bigler et al. reported that psychoactive drugs, such as MPH, caused different stress hormone profiles (2). Luethi et al. investigated MPH-based designer drugs and tested the potencies

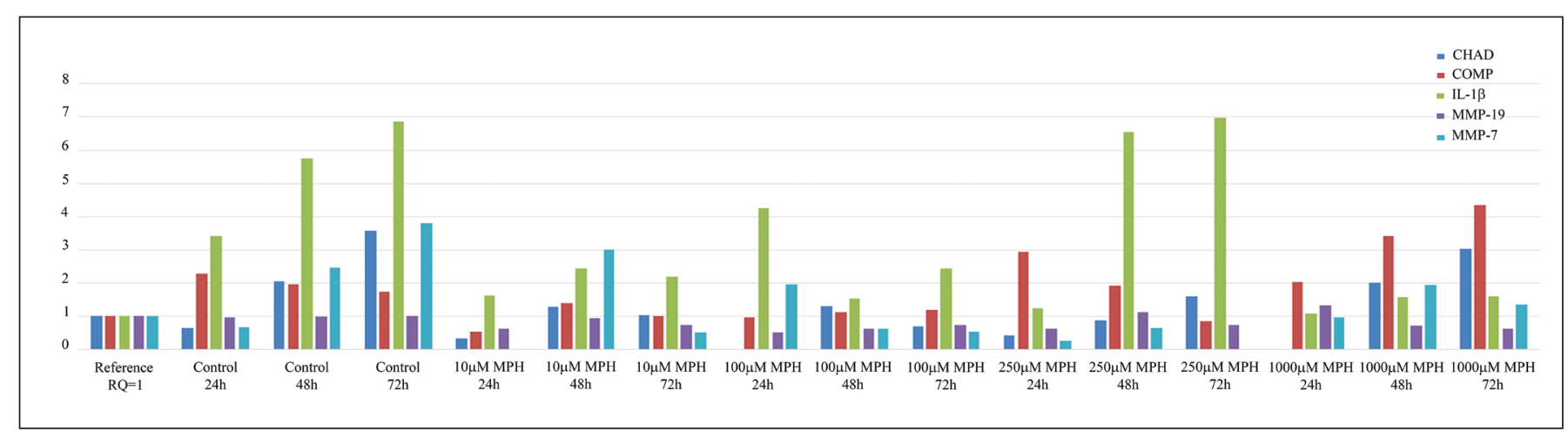

Figure 3: Comparative RT-PCR results using a reference (calibrator) sample (Control, $0 \mathrm{~h}$ ). The relative quantity (RQ) values were calculated using the $2 \Delta \Delta \mathrm{Cq}$ method. 
of the MPH-based N-benzylethylphenidate, 3,4-dichloroethylphenidate, 3,4-dichloromethylphenidate, ethylnaphthidate, ethylphenidate, 4-fluoromethylphenidate, isopropylphenidate, 4-methylmethylphenidate, methylmorphenate, and propylphenidate, as well as the potencies of the relevant compounds cocaine and modafinil, in terms of norepinephrine, dopamine, and serotonin transporter inhibition in HEK-293 cells (18). In that study, monoamine efflux, monoamine receptor, and transporter binding affinities were also investigated. The authors concluded that the MPH-based substances inhibited the norepinephrine and dopamine transporters with 4 to 1000 -fold greater potency when compared with the serotonin transporter (18). The MPH-based substances did not induce transportermediated flow of monoamines, as this flow was the same for MHP as for cocaine (18). The authors emphasized that many test drugs had an affinity for adrenergic, serotonergic, and rat trace amine-associated receptors, but not for DA or mouse trace amine-associated receptors (18). No cytotoxicity was observed after drug treatment at the analyzed concentrations, and MPH-based chemicals were reported to have pharmacological effect profiles similar to those of MPH and cocaine (18).

The results obtained from studies based on animal models may differ from those obtained in human studies, so that the results may be misleading $(6,10)$. The sensitivities of human and animal tissues differ, and commercial cell lines contain a single type cell and do not have their original phenotypic and genotypic characteristics $(6,9-11)$. For these reasons, in the present study, we did not use animal tissues or commercial cell lines. Instead, we prepared human primary cell cultures from intact human intervertebral disc tissue. We believe that this difference may contribute to the value of the present study.

These human primary cell cultures were used to examine the effects of MPH on the expression of several important genes in IVD tissues. CHAD is a cartilage matrix protein that promotes the adhesion of NPCs, chondrocytes, fibroblasts, and osteoblasts $(12,13)$, mediated by integrin alpha and beta (11). CHAD therefore plays a significant role in the regulation of chondrocyte growth and proliferation (11-13). The COMP gene encodes the cartilage oligomeric matrix protein found in the extracellular matrix of the cells that make up ligaments and tendons and the near cartilage-forming cells. COMP plays a role in cell growth and proliferation, as well as in the regulation of cell movement and attachment. It may also be involved in the pathogenesis of osteoarthritis and may serve as a potent suppressor of apoptosis in primary chondrocytes, intervertebral disc cells, and transformed cells (11-13). IL$1 \beta$ is a proinflammatory cytokine that induces prostaglandin synthesis; neutrophil influx and activation; T-cell activation and cytokine production; B-cell activation and antibody production; and fibroblast proliferation and collagen production in the extracellular matrix $(20,28)$. MMP-7 and MMP-19 are members of the matrix metalloproteinase (MMP) family consisting of structural-related zinc-dependent endopeptidases. The primary role of cleaved/activated MMP is to break down the extracellular matrix by degrading macromolecules like casein, gelatin, fibronectin, and proteoglycan $(4,27)$.
Cell viability and proliferation were gradually decreased as the exposure to MPH increased. The results of the qRT-PCR analysis indicated that differences in the applied doses and the durations of administration changed the expressions of all the genes. The analyses were repeated three times using samples obtained from six patients; however, the small sample size precluded the demonstration of a clear correlation between dosage and gene expression changes. The MTT analysis and $\mathrm{AO} / \mathrm{PI}$ staining revealed a decrease in cell proliferation and apoptotic cell death. Although the administration of the highest dose MPH was expected to increase cell death, the highest cell death was observed following the application of $100 \mu \mathrm{M} \mathrm{MPH}$ at $24 \mathrm{~h}$, in agreement with the qRT-PCR analyses. The lowest gene expression change was actually observed following the highest dose administration.

In humans, MPH is metabolized in the liver in the form of phenyl piperidine acetic acid (PPAA), which has little or no pharmacological activity. The present study was carried out in an in vitro environment, so the effect of PPAA, a de-esterified metabolite, on IVD tissue cells cannot be clearly explained. The present study has a number of limitations, so studies that incorporate a larger number of participants should be performed to provide a clear explanation.

\section{- CONCLUSION}

The data obtained from in vitro studies may not be directly adaptable to clinical applications. However, the fact that $\mathrm{MPH}-\mathrm{a}$ central nervous system stimulant pharmaceutical preparation frequently prescribed for the treatment of ADHD, narcolepsy, and chronic fatigue syndrome-may suppress IVD tissue cell proliferation should be considered carefully by clinicians.

\section{REFERENCES}

1. Batterson KD, Southard KA, Dawson DV, Staley RN, Qian F, Slayton RL: The effect of chronic methylphenidate administration on tooth maturation in a sample of Caucasian children. Pediatr Dent 27: 292-297, 2005

2. Bigler MB, Egli SB, Hysek CM, Hoenger G, Schmied L, Baldin FS, Marquardsen FA, Recher M, Liechti ME, Hess C, Berger CT: Stress- induced in vivo recruitment of human cytotoxic natural killer cells favors subsets with distinct receptor profiles and associates with increased epinephrine levels. PLoS One10:e0145635, 2015

3. Chen FH, Herndon ME, Patel N, Hecht JT, Tuan RS, Lawler J: Interaction of cartilage oligomeric matrix protein/ thrombospondin 5 with aggrecan. J Biol Chem 282:2459124598, 2007

4. Gokay NS, Yilmaz I, Komur B, Demiroz AS, Gokce A, Dervisoglu S, Gokay BV: Acomparison of the effects of neuronal nitric oxide synthase and inducible nitric oxide synthase inhibition on cartilage damage. Biomed Res Int 2016: 7857345, 2016

5. Goldman RD: ADHD stimulants and their effect on height in children. Can Fam Physician 56:145, 146, 2010 
6. Gumustas F, Yilmaz I, Sirin DY, Gumustas SA, Batmaz AG, Isyar M, Akkaya S, Mahirogullari M: Chondrocyte proliferation, viability, and differentiation is declined following administration of methylphenidate utilized for the treatment of attentiondeficit/hyperactivity disorder. Hum Exp Toxicol 36:981-992, 2017

7. Gumustas F, Yilmaz I, Yulaf Y, Gokce S, Sabuncuoglu O: Empathy and facial expression recognition in children with and without attention-deficit/hyperactivity disorder: Effects of stimulant medication on empathic skills in children with attention-deficit/hyperactivity disorder. J Child Adolesc Psychopharmacol 27:433-439, 2017

8. Haleem-Smith H, Calderon R, Song $\mathrm{Y}$, Tuan RS, Chen $\mathrm{FH}$ : Cartilage oligomeric matrix protein enhances matrix assembly during chondrogenesis of human mesenchymal stem cells. J Cell Biochem 113:1245-1252, 2012

9. Karaarslan N, Batmaz AG, Yilmaz I, Ozbek H, Caliskan T, Sirin DY, Kaplan N, Oznam K, Ates O: Effect of naproxen on proliferation and differentiation of primary cell cultures isolated from human cartilage tissue. Exp Ther Med 16:16471654, 2018

10. Karaarslan N, Yilmaz I, Ozbek H, Sirin DY, Kaplan N, Akyuva Y, Gonultas A, Ates O: Are specific gene expressions of extracellular matrix and nucleus pulposus affected by primary cell cultures prepared from intact or degenerative intervertebral disc tissues? Turk Neurosurg 29:43-52, 2019

11. Karaarslan N, Yilmaz I, Ozbek H, Sirin DY, Kaplan N, Caliskan T, Ozdemir C, Akyuva Y, Ates O: Are radio-contrast agents commonly used in discography toxic to the intact intervertebral disc tissue cells? Basic Clin Pharmacol Toxicol 124:181-189, 2019

12. Karaarslan N, Yilmaz I, Sirin DY, Baykiz D, Demirkiran A, Ates O: Do we damage nucleus pulposus tissue while treating cerebrovascular ischemic neurological deficits with nimodipine? Ann Med Res 25:266-273, 2018

13. Karaarslan N, Yilmaz I, Sirin DY, Ozbek H, Kaplan N, Kaya YE, Akyuva Y, Gurbuz MS, Oznam K, Ates O: Pregabalin treatment for neuropathic pain may damage intervertebral disc tissue. Exp Ther Med 16:1259-1265, 2018

14. Karlstad $\varnothing$, Zoëga H, Furu K, Bahmanyar S, Martikainen JE, Kieler $\mathrm{H}$, Pottegård A: Use of drugs for ADHD among adults-a multinational study among 15.8 million adults in the Nordic countries. Eur J Clin Pharmacol 72:1507-1514, 2016

15. Komatsu DE, Thanos PK, Mary MN, Janda HA, John CM, Robison L, Ananth M, Swanson JM, Volkow ND, Hadjiargyrou M: Chronic exposure to methylphenidate impairs appendicular bone quality in young rats. Bone 50: 1214-1222, 2012

16. Kwon WK, Moon HJ, Kwon TH, Park YK, Kim JH: The role of hypoxia in angiogenesis and extracellular matrix regulation of intervertebral disc cells during inflammatory reactions. Neurosurgery 81:867-875, 2017
17. Ludolph AG, Schaz U, Storch A, Liebau S, Fegert JM, Boeckers TM: Methylphenidate exerts no neurotoxic, but neuroprotective effects in vitro. J Neural Transm (Vienna) 113:1927-1934, 2006

18. Luethi D, Kaeser PJ, Brandt SD, Krähenbühl S, Hoener MC, Liechti ME: Pharmacological profile of methylphenidatebased designer drugs. Neuropharmacology 134:133-140, 2018

19. Mancano MA: Trimethoprim-sulfamethoxazole-induced rhabdomyolysis; gabapentin-induced hypoglycemia in diabetic and nondiabetic patients; purple glove syndrome after oral phenytoin administration; acute dystonic reaction after methylphenidate initiation; serotonin syndrome with vilazodone monotherapy; cabozantinib-associated dermatologic adverse reactions. Hosp Pharm 50:662-666, 2015

20. Panasyuk A, Colantuoni G, Khatib AM, Lomri A, Mitrovic DR: Human synovium produces substances that inhibit DNA and stimulate proteoglycan and collagensynthesis by cultured human articular chondrocytes and synovial fibroblasts. Scand J Rheumatol 32: 240-246, 2003

21. Sirin DY, Karaarslan N: Evaluation of the effects of pregabalin on chondrocyte proliferation and CHAD, HIF-1a, and COL2A1 gene expression. Arch Med Sci 14:1340-1347, 2018

22. Tehranchi A, Younessian F, Fadaei V, Arabgol F, Shirvani A: The effect of methylphenidate on cervical vertebral maturation and dental age in patients with attention deficit hyperactivity disorder. J Dent (Shiraz) 19:197-205, 2018

23. Trivedi A, Zhang H, Ekeledo A, Lee S, Werb Z, Plant GW, Noble-Haeusslein LJ: Deficiency in matrix metalloproteinase-2 results in long-term vascular instability and regression in the injured mouse spinal cord. Exp Neurol 284:50-62, 2016

24. Vadivelu S, Stewart TJ, Qu Y, Horn K, Liu S, Li Q, Silver J, McDonald JW: NG2+ progenitors derived from embryonic stem cells penetrate glial scar and promote axonal outgrowth into white matter after spinal cord injury. Stem Cells Transl Med 4:401-411, 2015

25. Vitiello B: Understanding the risk of using medications for attention deficit hyperactivity disorder with respect to physical growth and cardiovascular function. Child Adolesc Psychiatr Clin N Am 17:459-474, 2008

26. Vogt I, Prinz J, Campillos M: Molecularly and clinically related drugs and diseases are enriched in phenotypically similar drug-disease pairs. Genome Med 6:52, 2014

27. Yilmaz I, Gokay NS, Bircan R, Saracoglu GV, Dervisoglu S, Gokce A: How different methodologies of harvesting and analysing the samples affect the test results in determining joint mediators. Arthritis 2013: 631959, 2013

28. Zherebiatiev A, Kamyshnyi A: Expressionlevels of proinflammatory cytokines and NLRP3 inflammasome in an experimental model of oxazolone-induced colitis. Iran J Allergy Asthma Immunol 15:39-45, 2016 